\title{
Suitable Land Assessment for Rice Crop in Burkina Faso Using GIS, Remote Sensing and Multi Criteria Analysis
}

\author{
Gnibga Issoufou Yangouliba1,2,3*, Daniel Kwawuvi1,2, Adrian Almoradie ${ }^{4}$ \\ ${ }^{1}$ West Africa Science Service Centre on Climate Change and Adapted Land Use, University of Abomey Calavi, Abomey-Calavi, \\ Benin \\ ${ }^{2}$ Laboratory of Applied Hydrology, University of Abomey-Calavi, Abomey-Calavi, Benin \\ ${ }^{3}$ Department of Geography, University Joseph Ki-Zerbo, Ouagadougou, Burkina Faso \\ ${ }^{4}$ Department of Geography, University of Bonn, Meckenheimer Allee, Germany \\ Email: *yangis2000@yahoo.fr
}

How to cite this paper: Yangouliba, G.I., Kwawuvi, D. and Almoradie, A. (2020) Suitable Land Assessment for Rice Crop in Burkina Faso Using GIS, Remote Sensing and Multi Criteria Analysis. Journal of Geographic Information System, 12, 683-696. https://doi.org/10.4236/igis.2020.126039

Received: November 6, 2020

Accepted: December 7, 2020

Published: December 10, 2020

Copyright $\odot 2020$ by author(s) and Scientific Research Publishing Inc. This work is licensed under the Creative Commons Attribution International License (CC BY 4.0).

http://creativecommons.org/licenses/by/4.0/

\begin{abstract}
In Burkina Faso, rice consumption is currently common and increasing in both, rural and urban areas. Although several efforts have been made by the state to develop land for rice cultivation, the population's demand is still greater than the supply. Nevertheless, the country has great potential for rice cultivation. This study aims to analyze the suitability of land for rice cropping in the province of Nahouri. Field and satellite data were collected to map the rice crops developed areas. Furthermore, morphopedological, topographic, land use/cover, and accessibility to land data were collected and integrated into a Geographic Information System (GIS) based on simple Multi-Criteria Analysis (MCA). Land suitability for rice crop was performed. The results show that the total suitable area for rice cultivation in the province is 106,373 ha ( $28 \%$ of the province) where the most suitable areas cover 32,614 ha and the suitable areas cover 73,759 ha. Already 3144 ha of the province area had been developed for rice cultivation with 815 ha and 845 ha of most suitable and suitable areas respectively whereas more than $45 \%$ of the developed lands were not fit for the rice crop suitable land.
\end{abstract}

\section{Keywords}

Geographic Information System, Land Suitability, Multi-Criteria Analysis, Rice, Remote Sensing

\section{Introduction}

Burkina Faso is a Sahelian country where agricultural activities employ about 80 
per cent of the occupied population and contribute to 35 - 40 per cent of the gross domestic product [1]. The various agricultural productions include cereals, oilseeds, tubers, cotton, and sugar cane. Among the cereals, rice is the one that is subject to massive imports. Indeed, rice cultivation occupies a marginal place in cereal production, causing production deficits every year. Over 2014-2015, the national average production of rice was 191,126 tons, i.e. 1/3 of the demand [2] although the country has a significant potential for rice production about 800,000 ha of lowlands [1]. The annual exploited areas are estimated at 60,000 ha in 2005 [3]. The rice growing facilities carried out are far from being able to satisfy the population's demand which is thus far greater than supply. As a result, the country is obliged to import around 393,830 tons of rice each year [2]. Indeed, the farmers use archaic cultivation methods and techniques which do not allow the use of certain suitable lands. [4] defines land suitability as the ability of a portion of land to tolerate the production of crops sustainably. They also argue that land suitability evaluation provides information on the constraints and opportunities for the use of the land and therefore guides decisions on optimal utilization of resources, whose knowledge is an essential prerequisite for land use planning and development. The lack of knowledge on suitable areas for crops has led researchers from the Institute of Environment and Agricultural Research (INERA) and the National Soil Office (BUNASOLS) to develop respectively rice varieties and soil characterisations to improve crops production.

Over the 45 provinces in Burkina Faso, there are only about 10 where rice is produced: Boulgou, Houet, and Comoé account for more than 40 per cent of the cultivated area. The Nahouri province ranks seventh, with 5.44 per cent of the country's rice-growing area [1]. It, therefore, appears to be an area that could play an important role in achieving food self-sufficiency because the area is very suitable for rice production [5]. However, few areas of land are being used for rice cultivation over there. Sometimes, some areas used by farmers are not often suitable for the crops produced [6]. To solve this problem, different tools had been used in the past to assess the suitability of land for crops. These include the subjective method, which requires the assessor to have experience and good knowledge of the area, and the objective method of assessment, which consists of assigning an index to the various soil variables according to the degree of their limitation to production [7]. Its implementation, however, is financially and time expensive when the study area is large [8] [9]. Also, although this method gives an opportunity for creating databases, it does not offer opportunities to assess spatially all the areas. Nevertheless, one of the main goals of the Ministry of Agriculture in Burkina Faso is to reach self-sufficiency in agricultural production. Therefore, land evaluation techniques need to be integrated to develop models for predicting land suitability for different types of crops [4] [9] [10]. This study aims to map the developments for rice crops and analyze the most suitable areas for rice cultivation in Nahouri Province by combining multi-criteria analysis, Geographic Information Systems (GIS), and remote sensing data. 


\section{Material and Methods}

\subsection{Study Area}

The study area is the province of Nahouri situated between longitudes $-0^{\circ} 40^{\prime} 45^{\prime \prime}$ and $-1^{\circ} 39^{\prime} 51^{\prime \prime}$ and latitudes $10^{\circ} 57^{\prime} 36^{\prime \prime}$ and $11^{\circ} 33^{\prime}$ (Figure 1 ). It is located in the south-central region of Burkina Faso and includes five communes (Po, Tiébélé, Guiaro, Zecco, and Ziou). Accessible by the National Road 5, the province covers an area of $3843 \mathrm{Km}^{2}$. It is bordered to the north by the provinces of Bazéga and Zoundwéogo, to the east by the province of Boulgou, to the west by Sissili and the south by the Republic of Ghana (Figure 1). The relief is dominated by glacis, interfluves, and fluvio-alluvial complexes with an average altitude of 306 meters. The hydrographic network is very dense with two major rivers (Sissili and Nazinon) and seven small dams. The province is located in the southern Sudanian zone with an average of precipitations around 800 to $900 \mathrm{~mm}$ per year. Nahouri is divided into two subareas that are the population pressure zone, and the classified forests zone. According to [11], there is a diversity of soils due to geological bedrock, geomorphology, and pedogenetic processes, which can be profitable for agriculture.

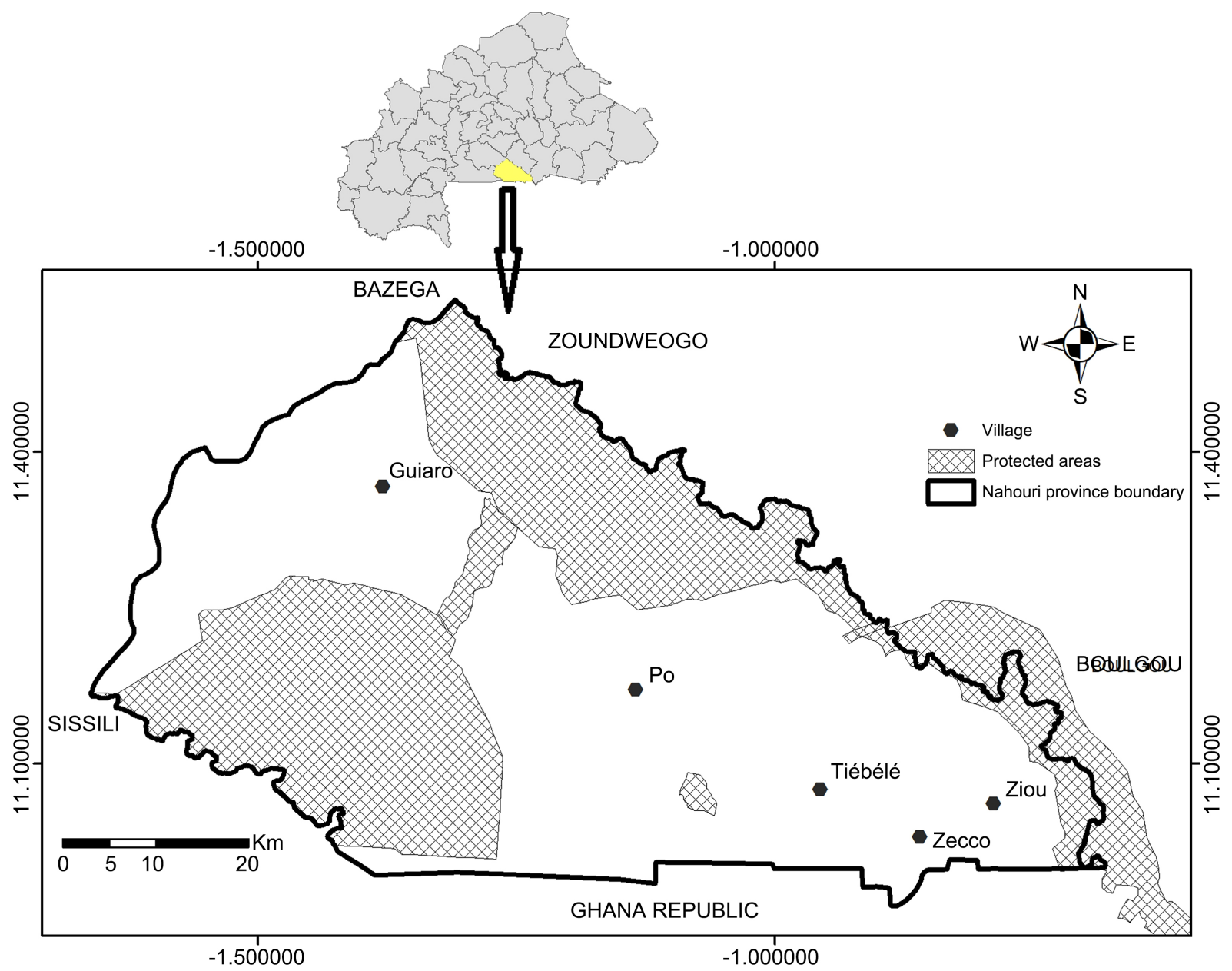

Figure 1. Map of the study area. 


\subsection{Mapping Rice Crops Developed Areas}

For mapping rice crops developed areas, a field survey has been done. Interviews were done with the agricultural technicians in each commune to know the location and the area of land developed for rice cultivation. With the Global Positioning System (GPS) coordinates, all the areas developed for rice cultivation have been delineated online using Google Earth satellite images (Figure 2). Google Earth satellite images are free and have a good spatial resolution, which allows viewing the contour of the developed areas. Additional information on developed land was also collected on their status and the funding institutions. The spatial data collected have been transferred in ArcGIS for mapping and geometrical analysis.

\subsection{Data for Rice Crops Land Suitability Assessment}

The suitable land analysis for rice production is based on a simple Multi-Criteria Approach or Analysis (MCA) through GIS. Indeed, new technologies such as remote sensing and GIS play an important role in mapping crops suitable land for developing countries [12] [13]. MCA incorporates variables called criteria. Among the criteria, a distinction is made between constraints having a Boolean character (suitable or unsuitable land for the chosen objective) and factors expressing a variation, theoretically continuous, in the suitability for use [14] [15]. The purpose of the multi-criteria analysis is to support decision-making in problem-solving or complex choice contexts [16] [17] [18]. MCA-GIS are flexible, participative and adaptable methods and can be applied for differing objectives at different planning scales. This combined method was used by [19] to assess flood vulnerability in a case study in Brazil by conducting a sensitivity and uncertainty analysis. [20] assessed the environment sensitivity in Ireland by using this method to anticipate potential significant impacts and inform the development and assessment of planning alternatives. [21] mapped the optimal

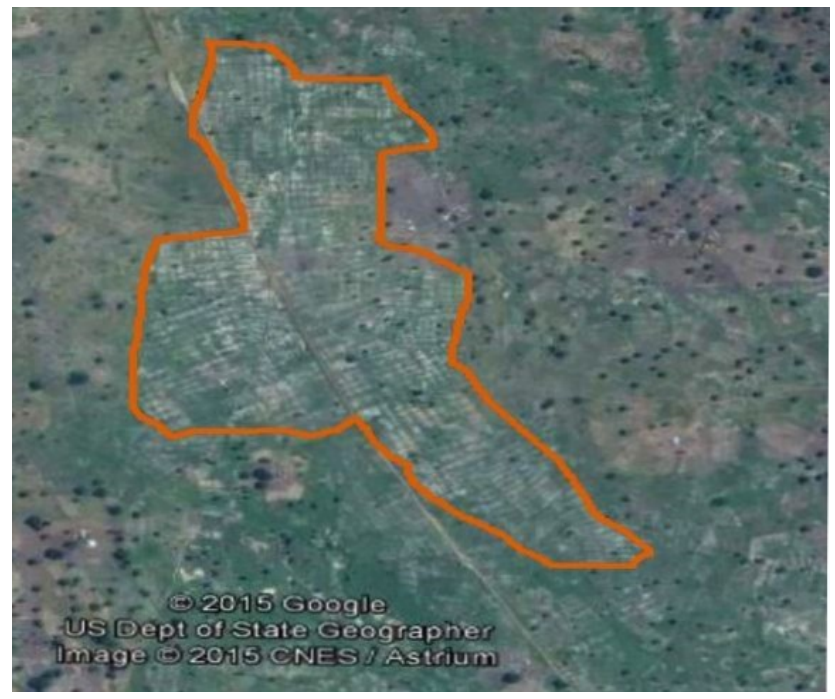

Figure 2. Delineation of a rice cop developed area in Yorgo, Nahouri province. 
locations for rainfed rice production in India using five variables: nutrient availability, elevation, slope, annual precipitation and current land cover. [22] also con-ducted land suitability analysis for rice cultivation in the Morobe province in the Papua New Guinea. In their study, the analysis was based on variables such as topography, physical and chemical soil properties, climate (temperature and rainfall) data and land accessibility. In this study, however, four types of data (morphopedological data, topographic data, land use land cover, and land accessibility) were used in the suitability assessment as they are easily accessible and also reliable. According to [23], land suitability for rice cultivation depends mainly on slope, soil, water availability. The major soil characteristics are topography, wetness, soil texture, soil depth, soil acidity $(\mathrm{pH})$, base saturation and soil organic carbon [24]. A rainfall of more than $800 \mathrm{~mm}$ is suitable for rice cultivation, optimum temperature of $>12^{\circ} \mathrm{C}$ for seed germination and $24^{\circ} \mathrm{C}$ $36^{\circ} \mathrm{C}$ for optimum growth is required [24]. In this study, the main assumption is that the climate conditions (rainfall and temperature) in the province are suitable for rice production.

\subsubsection{Morphopedological Data}

Morphopedological data were defined by [11] according to soil mapping and pedological committee (CPCS), and refers to soil fertility. [11] identified five pedological units in the province:

1) Soils with raw minerals have a depth of less than $10 \mathrm{~cm}$ do not have a great agricultural utility. The lack of land obliges some farmers to use the hillsides that support them for cereal crops. But rice cultivation is very difficult, if not impossible because the slope does not allow a great water holding capacity;

2) Few developed soils distinguish three subgroups: the subgroup of few developed erosion soils, the subgroup of few developed alluvial soils, and the subgroup of few developed colluvial input soils. The few developed soils are young. This gives them a particularity in their use according to the different subgroups and cropping patterns. These soils, except the subgroup of erosion soils, are used for all crops. Rice cultivation is suitable on few developed alluvial and colluvial soils [11].

3) Browned soils are derived from basic rock alteration materials. They are soils that on the whole have a medium structure with a fine to medium texture dominated by montmorillonite clays. Due to their texture, they are considered the richest soils in the province. Rice cultivation is very suitable on these soils [11].

4) Soils with iron or manganese sesquioxides: they are mostly made up of the group of leached tropical ferruginous soils. They are sometimes indurated and have impermeable horizons. This does not allow root penetration. Their fertility is average and depends mainly on the content of altered mineral elements. These soils are not suitable for rice cultivation. However, they are quite suitable for other cereal crops [11].

5) Hydromorphic soils are formed on alluvial material marked by temporary 
or perennial excess water. They are deep with moderate to imperfect drainage and are characterized by temporary and partial hydromorphism. Hydromorphic soils are very suitable for rice crops.

Pedological and geomorphological units have been combined to create a morphopedological map with eight new units [11]. Then, morphopedological units that are suitable for rice crop cultivation were identified (Table 1). After reclassification, a map of suitable morphopedological capacity of rice production presented in Figure 3 was obtained.

Table 1. Characteristics of criteria, attributes and their suitability for rice cultivation.

\begin{tabular}{|c|c|c|}
\hline Criteria & Attributes & Suitability \\
\hline & Settlement & Unsuitable \\
\hline & Irrigated crops & Suitable \\
\hline & Rainfed crops and agroforestry & Suitable \\
\hline & Open forest & Suitable \\
\hline & Gallery forest & Suitable \\
\hline \multirow[t]{7}{*}{ LULC } & Wood savanna & Suitable \\
\hline & Shrub savanna & Suitable \\
\hline & Orchard & Suitable \\
\hline & Bare soils & Unsuitable \\
\hline & Water bodies & Unsuitable \\
\hline & Wetlands & Suitable \\
\hline & $>3$ & Unsuitable \\
\hline \multirow[t]{5}{*}{ Slope (\%) } & $1-3$ & Suitable \\
\hline & $<1$ & Most suitable \\
\hline & Lithosols & Unsuitable \\
\hline & Brown eutrophic tropical ferruginous soils & Suitable \\
\hline & Few developed tropical eutrophic brown soils & Most suitable \\
\hline \multirow{6}{*}{$\begin{array}{l}\text { Morphopedologic } \\
\text { units }\end{array}$} & Medium-deep indurated ferruginous leached soils & Unsuitable \\
\hline & Shallow indurated ferruginous leaching soils & Unsuitable \\
\hline & Leached tropical ferruginous soils with concretions & Unsuitable \\
\hline & Leached tropical ferruginous soils with spots and concretions & Unsuitable \\
\hline & Few developed soils with colluvial input, hydrmorphs & Most suitable \\
\hline & Classified areas/forests & Unsuitable \\
\hline \multicolumn{3}{|l|}{ Land accessibility } \\
\hline & Unclassified areas & Suitable \\
\hline
\end{tabular}




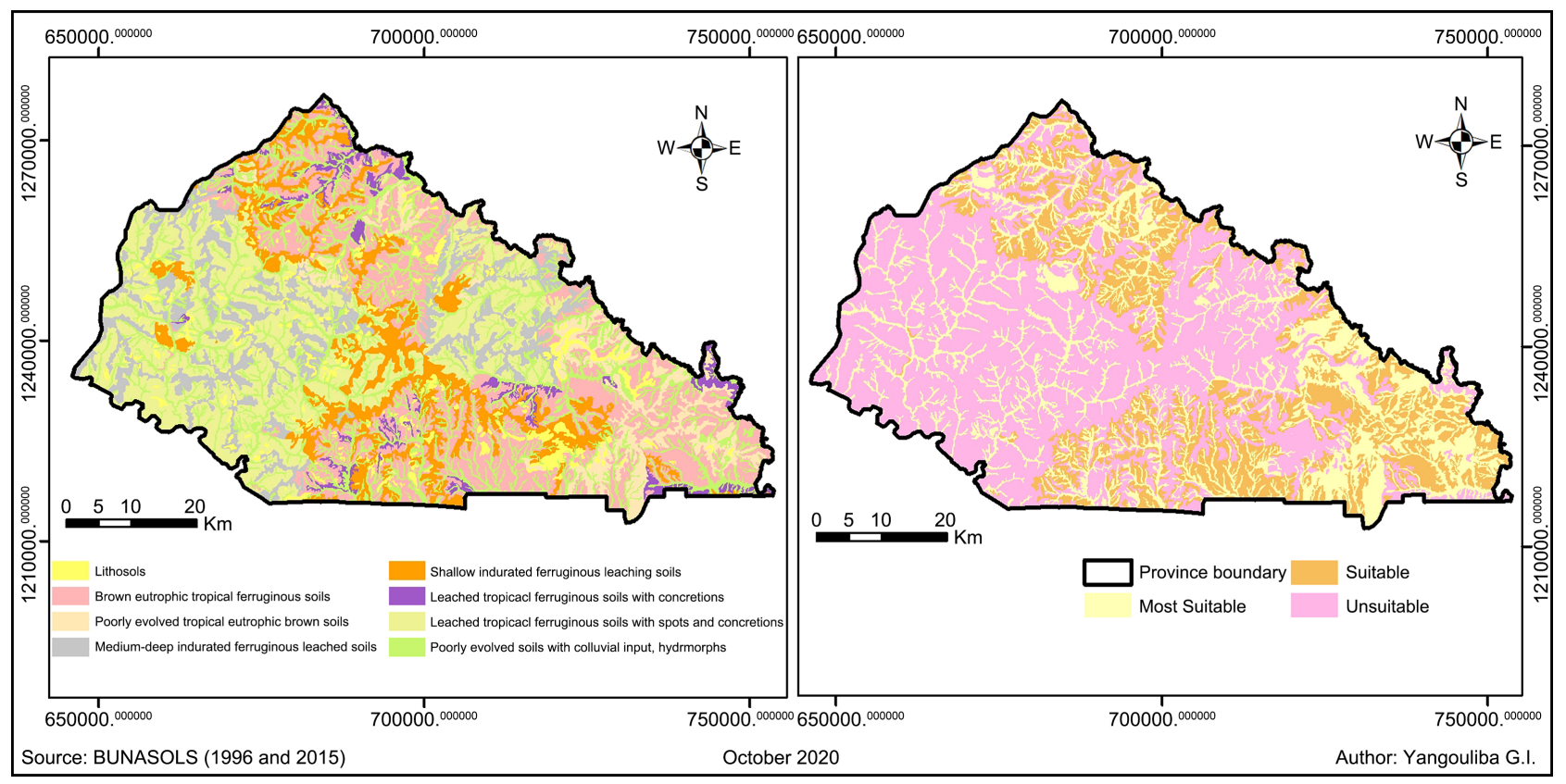

Figure 3. Morphopedological units of the study area (left); Suitability of the morphopedological units (right).

\subsubsection{Topographic Data}

Topography plays a key role in the agricultural process. Slope contributes not only to the determination of soil characteristics but also to drainage [25]. The slope of the land determines water runoff as it is a determining factor in the process of water control. It is one of the important data layers whose areas with low slopes ideally suited for rice cultivation since they require very little investment for land preparation, presence of rich fertile soils, and adequate water [23]. For this study, a Shuttle Radar Topography Mission (SRTM) image was downloaded from the United States Geological Survey data gateway (www.usgs.gov). A contour line map has been created firstly. Then, the latter has been rasterised to get a slope map which after reclassification has been vectorised (Figure 4). The area with lower and medium slopes and smooth surface were considered as most suitable and suitable respectively for rice cultivation (Table 1 ) as they facilitate equal distribution of water, good surface drainage and less exposed to erosion [22]. Many studies showed that suitable slopes for rice cultivation are generally less than 3\% [21] [23] [26] [27]. Thus, for this study, areas whose slopes are less than $1 \%$ are considered as most suitable. Those between $1 \%$ and $3 \%$ are suitable while slopes greater than $3 \%$ are not suitable (Table 1 ).

\subsubsection{Land Use Land Cover}

Data of 2015 land use land cover was collected from the Geographical Institute of Burkina Faso (IGB). From that database, eleven land use land cover classes are identified: settlement, irrigated crops, rainfed crops and agroforestry, open forest, gallery forest, wood savanna, shrub savanna, orchard, bare soils, water bodies and wetlands (Figure 5). Among these classes, some are not usable for rice production. Therefore, binary coefficients have been attributed to the land use 


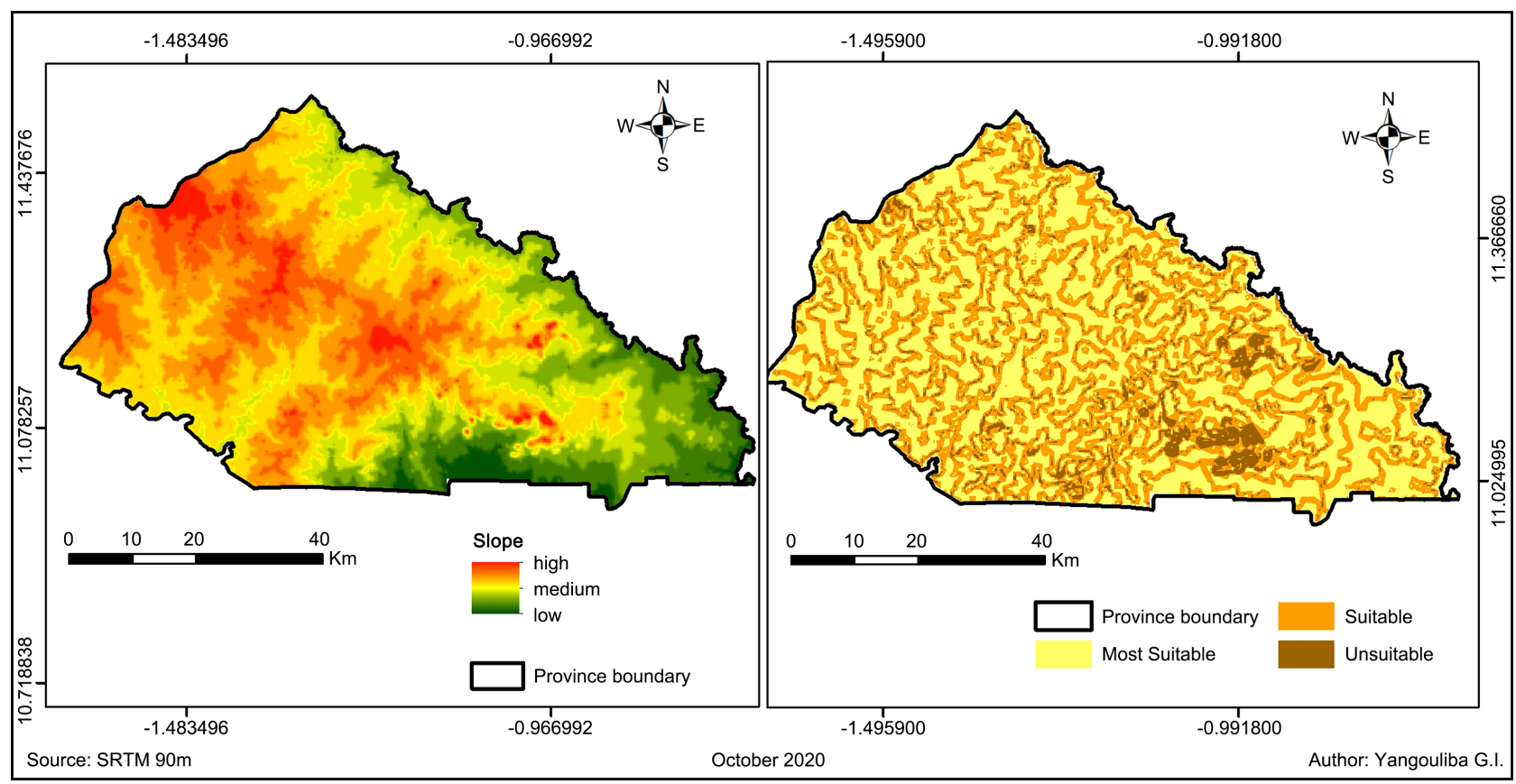

Figure 4. Topography of the study area (left); Suitability of the slope (right).

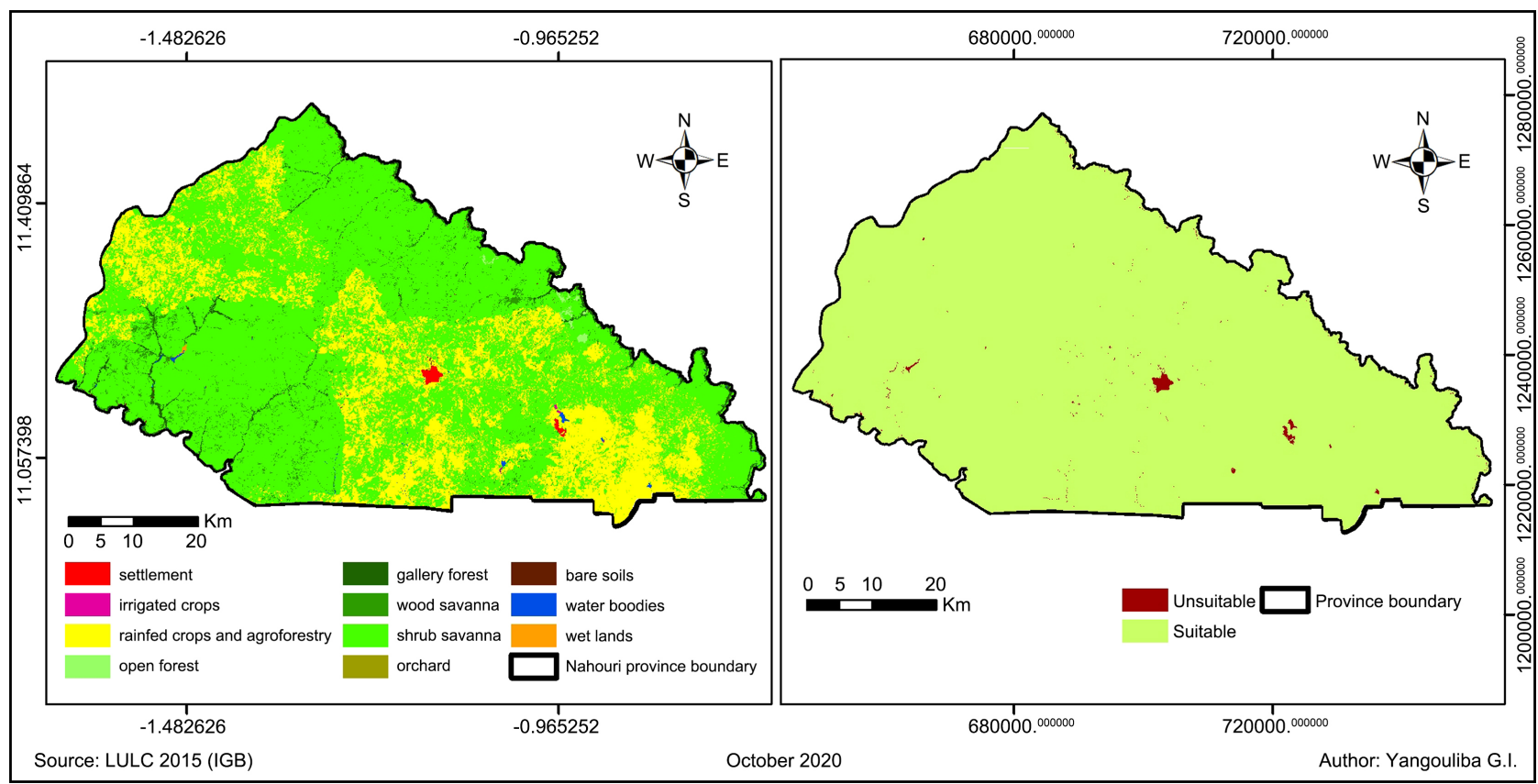

Figure 5. Land use land cover of the study area (left); Suitability of the land use land cover (right).

classes. For instance, classes like fallows and vegetation can be used for rice production but not water bodies and settlement. All the description of the suitability for each attribute is given in Table 1.

\subsubsection{Land Accessibility}

The land accessibility is mainly related to the two subareas predefined that are the population pressure zone and the classified forests zone. Indeed, it is not 
possible to use the protected areas for farming. They are natural forest reserves of flora and wildlife where human activities are forbidden. The National Park Kaboré Tambi was created in 1936 and classified in 1986 whereas the Nazinga Game Ranch, a natural wildlife reserve was created in 1979 [28]. The third one which is the elephant migration corridor was developed between 2003 and 2007. It links the two first forest to enable the elephant to migrate from Burkina Faso to Ghana through the Red Volta River. A collective forest also exists in the commune of Pô. Thus, a significant proportion of the provincial area (40\%) is subject to protection (Figure 1).

\subsection{Analysis of Rice Crops Land Suitability}

For the analysis of the land suitability for rice cultivation, the conceptual framework designed in Figure 6 was used. It is a method based on the combination of GIS-MCA as used by [17] who stated that improvement of the capacities of GIS in the decision-making can be achieved by the introduction of multi-criteria techniques in the GIS environment. For this study, the method of tight coupling strategy was used to integrate GIS and MCA. The tight coupling strategy uses multiple criteria evaluation functions fully integrated into GIS, a shared database and a common user interface [17]. In the approach used for this study, all the criteria have equal weights while the weights of attributes within each criterion vary [23]. Then, the rice cropland suitability was processed through database manipulation using the logic operators (AND, OR, NOT).

\section{Results and Discussion}

Some areas have been developed for rice cultivation in Nahouri province. Most of them are located in the lowlands or plains. These developments have been carried out by the State in collaboration with projects such as the Rainfed Rice Project (PRP), the Action Plan for the Rice Sector (PAFR), the second National Territorial Planning Program (PNGT2) and the West African Development Bank. Some of the developments are on their way collapsing because of a lack of care. Figure 8 displays the distribution of the rice crops areas developed in the province. It shows that the south-western part of the province does not have developed rice areas. The developments are more represented in the centre and

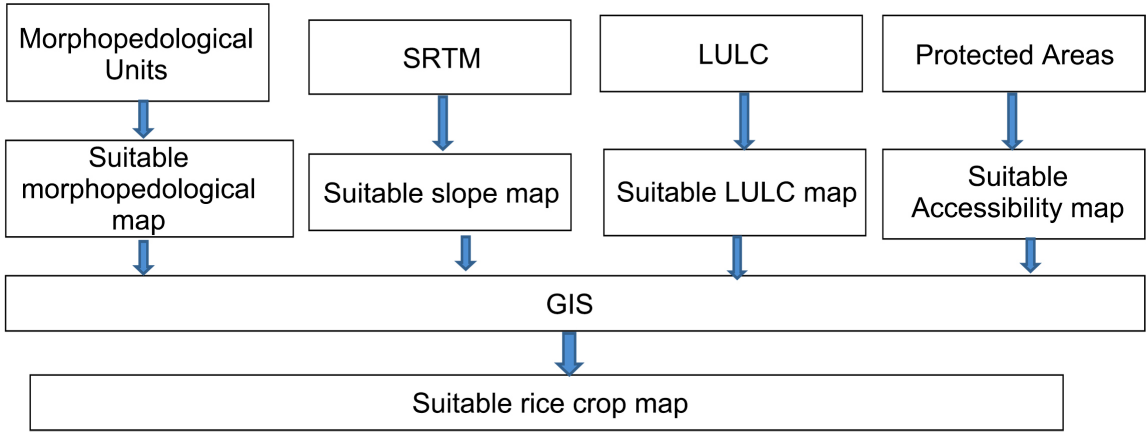

Figure 6. Conceptual framework of GIS-Multi-Criteria integration used for the study. 
south-eastern parts and occupy 3144 ha. This result is comparable to those found by [1] and the [29] who stated that about 3000 ha were used for rice crops cultivation in the Nahouri Province.

Over the whole province, based on the multi-criteria analysis, 106,373 ha of land are favourable for rice cultivation i.e. $28 \%$ of the total area. The most suitable areas are especially located in South-Eastern part of the province and cover 32,614 ha (more than $8 \%$ of Nahouri) while suitable areas cover 73,759 ha (19\% of Nahouri). There are three fourth of the province area where rice production is unsuitable (Figure 7). This inaptitude is due to fourfold unsuitability: morphopedology, land use, topography and land accessibility. [30] found that the main limitations for rice cultivation over West Africa are the quality of the soil especially their depth, erodibility and high Phosphorus fixation. The results were also supported by [31] and [10] in Nigeria and Ethiopia respectively. Over the 3144 ha developed for rice-growing purposes in the province, most of them are located on the hydromorphic soils. [11] found that those soils are the only soils used for rice cultivation even though excess water sometimes in the year is a disadvantage for their use. Only less than $3 \%$ of the favourable land is used and the province still has 103,229 ha of land that can support rice cultivation.

A superposition of the developed land layer on the favourable land layers indicates that more than $45 \%$ of the developments done in the province were not adequate based on the four criteria (Figure 8). Indeed, only 815 ha and 845 ha fitted well the most suitable and suitable areas respectively. This finding carries out the fitting problem of developments with crops suitability and could explain the low yield of rice in the province. The inadequation between the developments and suitable land could be explained by the difference of the soil map scale. The soil map used in this study has a fine scale of 1:100,000. However, a map with fine scale $(1: 500,000)$ exists and was used as guide for many land development projects in the country. The fine scale map provides more details

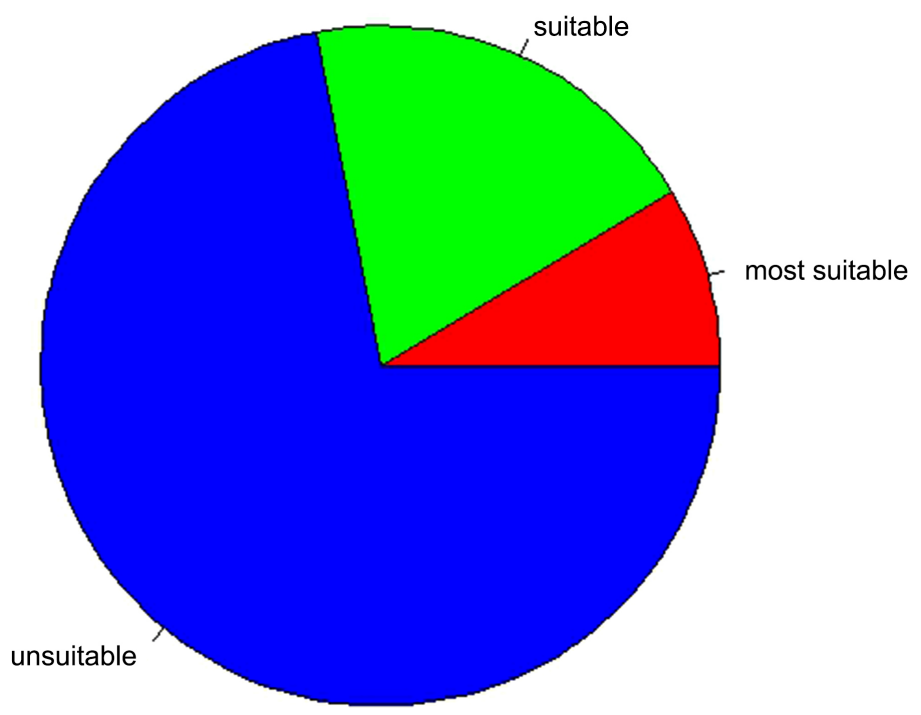

Figure 7. Percentage of rice crops land suitability in the study area. 


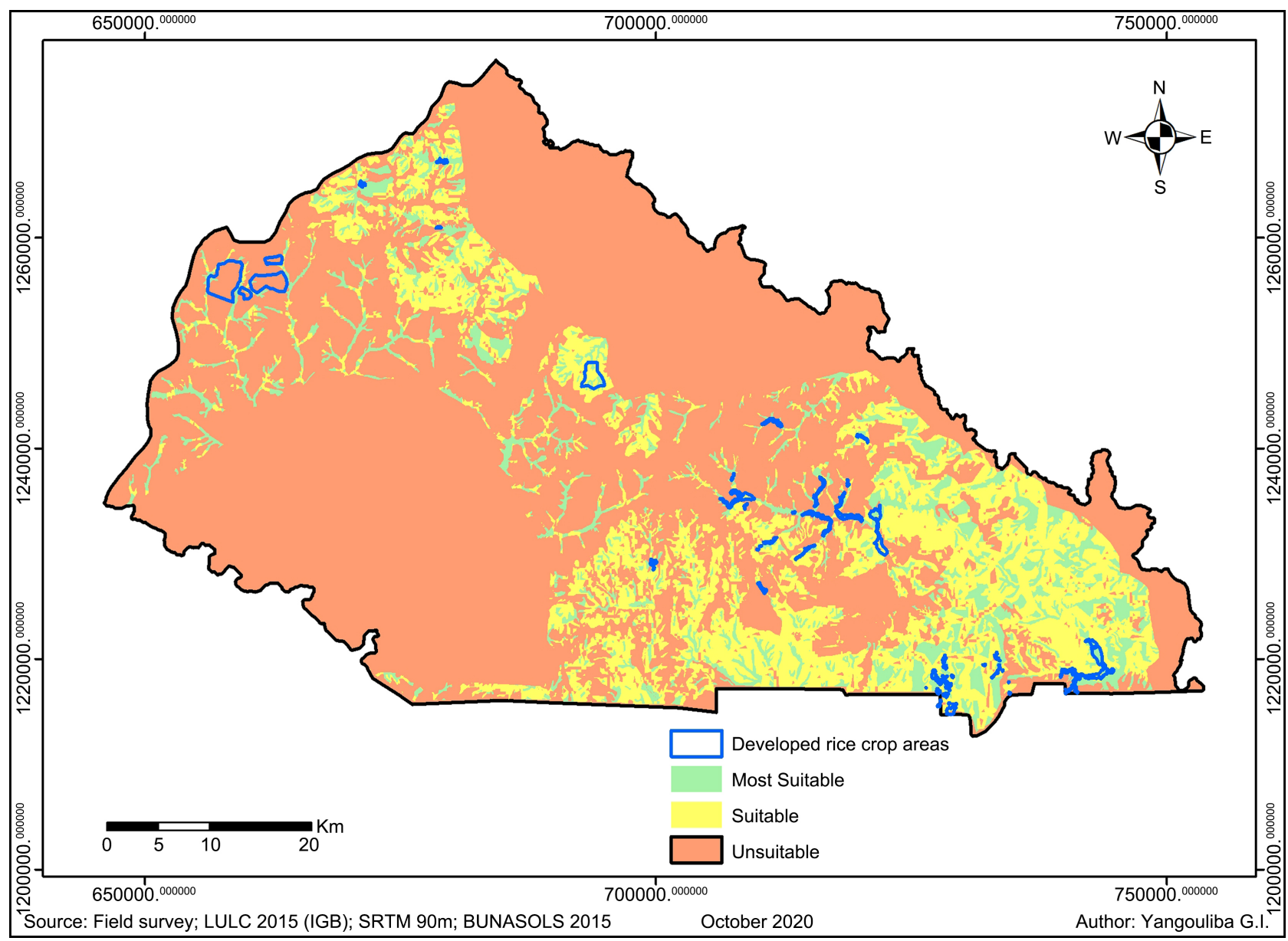

Figure 8. Correspondence of developed rice crop areas and suitable land.

on soil properties. Yet, [6] found that the yields of the two main food crops (rice and wheat) in India are far below their agronomic and genetic potential because they are not cultivated on suitable land. [32] indicated that some plants may be found to grow in poor soils and under extreme climatic conditions. Whatever the scale, in a developing country as Burkina Faso, the use of a combination GIS-MCA can help to increase the yields.

\section{Conclusion}

The identification of suitable areas for rice cultivation is well illustrated through the use of GIS, remote sensing data and multi-criteria analysis method. It is found that the rice-growing development in the Nahouri province was 3144 ha. The remaining favourable land available for rice production was 103,229 ha. These favourable areas correspond to plains or lowlands. The low-slope areas corresponding to the hydromorphic, colluvial and brown-eutrophic soils are the suitable areas for rice growing. The province can play an important role in rice cultivation, which can help the country to reach the food self-sufficient. The result of this study can be implemented and replicated over the whole country. Nevertheless, there is a need to assess land suitability taking into account rice 
varieties and farming practices through interviews with experts and farmers, as well as other crops like maize, millet and sorghum that are also much cultivated in the country.

\section{Acknowledgements}

The authors want to acknowledge the provision of data from the National Soil Office (BUNASOLS) and the Geographical Institute of Burkina Faso (IGB).

\section{Conflicts of Interest}

The authors declare no conflicts of interest regarding the publication of this paper.

\section{References}

[1] Kaboré, D.P. (2007) Efficience Technique de la Production Rizicole sur les Périmètres Aménagés du Burkina Faso. Série Document de Travail DT-CAPES No. 2007-35. CAPES, Ouagadougou, Burkina Faso.

[2] Food and Agriculture Organization (2015) Évaluation du Programme de la FAO au Burkina Faso 2010-2014: Etude de cas sur l'Aménagement de trois Bas-Fonds Rizicoles dans la Région Nord au Burkina Faso. http://www.fao.org/3/a-bd464f.pdf

[3] Guissou, R. and Ilboudo, F. (2012) Analyse des Incitations et Pénalisations Pour le riz au Burkina Faso. Série Notes Techniques, Suivi des Politiques Agricoles et Alimentaires en Afrique, Food and Agriculture Organization, Rome.

[4] Abdelrahman, M.A.E., Natarajan, A. and Hegde, R. (2016) Assessment of Land Suitability and Capability by Integrating Remote Sensing and GIS for Agriculture in Chamarajanagar District, Karnataka, India. Egyptian Journal of Remote Sensing and Space Science, 19, 125-141. https://doi.org/10.1016/j.ejrs.2016.02.001

[5] Sié, M., Zongo, J.D. and Dakouo, D. (1998) Prospection des Cultivars Traditionnels de riz du Burkina Faso. Sciences et Médecine, 21-27.

[6] Halder, J.C. (2013) Land Suitability Assessment for Crop Cultivation by Using Re-mote Sensing and GIS. Journal of Geography and Geology, 5, 65-74. https://doi.org/10.5539/jgg.v5n3p65

[7] Agbodjalou, C.H.M. (2009) Production du riz NERICA au Benin: Identification des Zones Propices par Analyse Géospatiale. Master professionnel en Géo-information et ses applications à la gestion intégrée des eaux et des écosystèmes. Université d'Abomey-Calavi.

https://www.memoireonline.com/06/11/4555/m Production-du-riz-nerica-au-beni n--identification-des-zones-propices-par-analyse-geospatiale $0 . h t m l$

[8] Campbell, J.B. (1987) Introduction to Remote Sensing. The Guilford Press, New York.

[9] Dengiz, O. (2013) Land Suitability Assessment for Rice Cultivation Based on GIS Modeling. Turkish Journal of Agriculture and Forestry, 37, 326-334. https://doi.org/10.3906/tar-1206-51

[10] Yohannes, H. and Soromessa, T. (2018) Land Suitability Assessment for Major Crops by Using GIS-Based Multi-Criteria Approach in Andit Tid Watershed, Ethiopia. Cogent Food \& Agriculture, 4, Article ID: 1470481.

https://doi.org/10.1080/23311932.2018.1470481 
[11] Bureau National des Sols (1996) Etude Morphopédologique de la Province du Nahouri, Échelle 1/100 000. Rapport Technique No. 101, Bureau National des Sols, Ouagadougou.

[12] Perera, L.K. and Tateishi, R. (1995) Do Remote Sensing and GIS Have a Practical Applicability in Developing Countries? International Journal of Remote Sensing, 16, 35-51. https://doi.org/10.1080/01431169508954370

[13] Kuria, D., Ngar, D. and Waithaka, E. (2011) Using Geographic Information Systems (GIS) to Determine Land Suitability for Rice Crop Growing in the Tana Delta. Journal of Geography and Regional Planning, 4, 525-532.

[14] Collins, M.G., Steiner, F.R. and Rushman, M.J. (2001) Land-Use Suitability Analysis in the United States: Historical Development and Promising Technological Achieve-Ments. Environmental Management, 28, 611-621. https://doi.org/10.1007/s002670010247

[15] Mustafa, A.A., Singh, M., Sahoo, R.N., Ahmed, N., Khanna, M. and Sarangi, A. (2011) Land Suitability Analysis for Different Crops: A Multi Criteria Decision Making Approach Using Remote Sensing and GIS. Researcher, 3, 61-84.

[16] Carver, S.J. (1991) Integrating Multi-Criteria Evaluation with Geographical Information Systems. International Journal of Geographical Information System, 5, 321-339. https://doi.org/10.1080/02693799108927858

[17] Gomes, E.G. and Lins, M.P.E. (2002) Integrating Geographical Information Sys-tems and Multi-Criteria Methods: A Case Study. Annals of Operations Research, 116, 243-269. https://doi.org/10.1023/A:1021344700828

[18] Malczewski, J. (2006) GIS-Based Multicriteria Analysis: A Survey of the Literature. International Journal of Geographic Information Science, 20, 703-726. https://doi.org/10.1080/13658810600661508

[19] de Brito, M.M., Almoradie, A. and Evers, M. (2019) Spatially-Explicit Sensitivity and Uncertainty Analysis in a MCDA-Based Flood Vulnerability Model. International Journal of Geographical Information Science, 33, 1788-1806. https://doi.org/10.1080/13658816.2019.1599125

[20] Gonzalez, A. and Enríquez-de-Salamanca Á. (2018) Spatial Multi-Criteria Analysis in Environmental Assessment: A Review and Reflection on Benefits and Limitations. Journal of Environmental Assessment Policy and Management, 20, Article ID: 1840001. https://doi.org/10.1142/S146433321840001X

[21] Goldman, D. (2013) Agricultural Suitability in India: Determining Optimal Locations for Rainfed Rice Production. http://sites.tufts.edu/gis/files/2013/11/Goldman Dana.pdf

[22] Samanta, S., Pal, B. and Pal, D.K. (2011) Land Suitability Analysis for Rice Cultiva-tion Based on Multi-Criteria Decision Approach through GIS. International Journal of Science \& Emerging Technologies, 2, 12-20.

[23] Gumma, M., Thenkabail, P.S., Fujii, H. and Namarac R. (2009) Spatial Models for Selecting the Most Suitable Areas of Rice Cultivation in the Inland Valley Wetlands of Ghana Using Remote Sensing and Geographic Information Systems. Journal of Applied Remote Sensing, 3, Article ID: 033537. https://doi.org/10.1117/1.3182847

[24] Food and Agriculture Organization (1983) Guidelines: Land Evaluation for Rainfed Agriculture. Food and Agriculture Organization Soils Bulletin 52, Rome, 237 p.

[25] Guindo, B. (2015) Identification des Sites Favorables à la Production Céréalière dans le Cercle de Bandiagara (Mali). Mémoire de Master en Science de la Géo-information, Obafemi Awolowo University, Osun State, Nigéria.

[26] Danvia, A., Jüttena, T., Giertza, S., Zwartb, S. J. and Diekkrüger B. (2016) A 
Spatially Explicit Approach to Assess the Suitability for Ricecultivation in an Inland Valley in Central Benin. Agricultural Water Management, 177, 95-106.

https://doi.org/10.1016/j.agwat.2016.07.003

[27] Mandal, D.K., Mandal, C., Raja, P. and Goswami, S.N. (2010) Identification of Suitable Areas for Aerobic Rice Cultivation in the Humid Tropics of Eastern India. Current Science, 99, 227-231.

[28] Dimobe, K., Goetze, D., Ouedraogo, A., Forkuor, G., Wala, K., Porembski, S. and Thiombiano, A. (2017) Spatio-Temporal Dynamics in Land Use and Habitat Fragmen-Tation within a Protected Area Dedicated to Tourism in a Sudanian Savanna of West Africa. Journal of Landscape Ecology, 10, 75-95.

https://doi.org/10.1515/jlecol-2017-0011

[29] MAHRH (2008) Résultats Définitifs de l'Enquete Permanente Agricole (EPA) 2006-2007. http://www.cns.bf/IMG/pdf/rapport 2006-2007

[30] Dondeyene, S., Deckers, J. and Raes, D. (1997) Land Evaluation for Irrigated Rice in the West African Sahel. In: Miézan, K.M., Wopereis, M.C.S., Dingkuhn, M., Deckers, J. and Randokph, T.R., Eds., Irrigated Rice in the Sahel: Prospects or Sus-Tainable Development, West Africa Rice Development Association, Saint Louis, 381-395.

[31] Olaleye, A.O., Ogunkunle, A.O., Sahrawat, K.L., Osiname, O.A. and Ayanlaja, S.A. (2002) Suitability Evaluation of Selected Wetland Soils in Nigeria for Rainfed Rice Cultivation. Tropicultura, 20, 97-103.

[32] Prasad, M.R., Reddy, G.K. and Govardhan, V. (2018) Soil-Site Suitability Evaluation for Rice and Wheat in Deccan Plateau Soil-Site Suitability Evaluation for Rice and Wheat in Deccan Plateau. Green Farming, 4, 169-172. 